\title{
Comparative application of direct sequencing, PCR-RFLP, and cytogenetic markers in the genetic characterization of Pimelodus (Siluriformes: Pimelodidae) species: Possible implications for fish conservation
}

\author{
M. Ferreira ${ }^{1}$, K.C.O. Bressane ${ }^{2}$, A.R.C. Moresco ${ }^{2}$, O. Moreira-Filho ${ }^{3}$, \\ L.F. Almeida-Toledo ${ }^{2}$ and C. Garcia ${ }^{1}$ \\ ${ }^{1}$ Departamento de Ciências Biológicas, \\ Universidade Estadual do Sudoeste da Bahia, Jequié, BA, Brasil \\ ${ }^{2}$ Departamento de Genética e Biologia Evolutiva, \\ Universidade de São Paulo, São Paulo, SP, Brasil \\ ${ }^{3}$ Departamento de Genética e Evolução, \\ Universidade Federal de São Carlos, São Carlos, SP, Brasil \\ Corresponding author: M. Ferreira \\ E-mail: milena_fro@hotmail.com \\ Genet. Mol. Res. 13 (2): 4529-4544 (2014) \\ Received May 27, 2013 \\ Accepted September 20, 2013 \\ Published June 17, 2014 \\ DOI http://dx.doi.org/10.4238/2014.June.17.5
}

\begin{abstract}
Pimelodus (Pimelodidae) is a genus comprising a group of South American species with complex taxonomic relationships. Cytogenetics, polymerase chain reaction restriction fragment length polymorphism (PCR-RFLP), and sequencing data of mitochondrial genes were analyzed to characterize 4 Pimelodus species: P. fur, P. heraldoi, P. maculatus, and Pimelodus sp. All populations presented $2 \mathrm{n}=56$ chromosomes and distinct karyotypic formulae. The heterochromatin distribution pattern and the number and location of $5 \mathrm{~S}$ and $18 \mathrm{~S}$ rDNA sites are discussed. The application of PCR-RFLP markers and sequencing of mitochondrial DNA genes provided species-specific haplotypes, which
\end{abstract}


allowed us to differentiate the species studied. The mitochondrial gene sequences presented nucleotide mutations in the restriction sites and throughout the sequences, and they were mostly related to synonymous substitutions in the coded proteins; however, they did not affect the protein and its function. Comparing the data obtained using these 3 methodologies, the existence of a species complex in P. maculatus along the basins studied might be inferred, showing that cytogenetics is an important tool in studies focusing on the conservation or management of both natural and captive populations of these fishes.

Key words: Conservation programs; Cytotypes; Restriction enzymes

\section{INTRODUCTION}

The family Pimelodidae is one of the largest families in Neotropical areas, comprising 83 valid species distributed into 50 genera, such as the genus Pimelodus, whose species are popularly known as "mandis" in Brazil. This genus is apparently paraphyletic, being restricted to South America and characterized by a complex taxonomy (Lundberg and Littmann, 2003). Among pimelodids, Pimelodus is the most genetically studied genus (Renesto et al., 2000; Swarça et al., 2000). Because several populations present quite similar morphological traits but distinctive genetic features, some species are commonly known as species complexes, like P. maculatus (Almeida et al., 2003) and P. albicans (Vergara et al., 2008).

Typically, cytogenetic studies in Siluriformes have focused on the description and characterization of the karyotypic variability within the group, while molecular analyses usually have been applied to elucidate the intricate phylogenetic interrelationships among their families. Only a few studies have attempted to define the evolutionary relationships among species of a single genus (Vergara et al., 2008). Cytogenetics and molecular genetics proved to be efficient in the characterization and differentiation of several species in fish studies. It was shown that the application of one of these approaches may help the other or, at least, it points out issues to be addressed when possible divergences are found (Almeida-Toledo et al., 2002).

In Brazil, most reports focusing on fish conservation genetics, either for the formation of genetic pools in aquaculture or for repopulation, are based on molecular techniques such as analyses of fragment length polymorphisms (RFLP) and amplification of nuclear DNA sequences flanked by microsatellites (SPAR). On the other hand, cytogenetic analyses have been overlooked because they are commonly regarded as time-consuming, dependent on a high number of methodologies, and specimens must be sacrificed (Toledo-Filho et al., 1999).

In this study, we attempted to analyze species of the genus Pimelodus from the main rivers from the Upper Paraná and São Francisco Basins by combining cytogenetic and molecular techniques to genetically characterize these populations. We also aimed to uncover evidence to confirm or refute the existence of a species complex in P. maculatus and to provide support for the potential of the selected markers in the identification of genetic groups in conservation programs.

\section{MATERIAL AND METHODS}

Specimens from 6 populations of P. maculatus that were collected in the following Bra- 
zilian municipalities were analyzed: Angatuba, SP, Brazil $(2+, 3 \hat{O}, 3$ juveniles-Paranapanema Basin), Guapiara, SP, Brazil (8, $4 \hat{\jmath}, 4$ juveniles-Paranapanema Basin), Itapetininga, SP, Brazil (2 juveniles-Tietê Basin), Três Lagoas Reservoir, Três Lagoas, MS, Brazil (3ㅇ, $2 \hat{0}$, 4 juveniles-Paraná Basin), Terra Roxa, SP, Brazil (6ㅇ, 20-Pardo Basin), and Três Marias, MG, Brazil (10ㅇ, $6{ }^{\lambda}$-São Francisco Basin). Individuals from a single population of $P$. fur-Três Marias, MG (10ㅇ, 3 3 -São Francisco Basin), P. heraldoi-Pirassununga, SP (6우, 50-Mogi-Guaçu Basin), and Pimelodus sp-Três Marias, MG (15q, 10 $\oint^{\lambda}$-São Francisco Basin) were also analyzed. All collected specimens were identified at the Museum of Zoology from Universidade de São Paulo.

\section{Cytogenetic analyses}

All individuals of $P$. maculatus from Angatuba, Guapiara, Três Lagoas, and Terra Roxa, and the specimens of $P$. heraldoi from Pirassununga were used in the cytogenetic analyses. The individuals of P. fur, P. maculatus, and Pimelodus sp. that were collected in Três Marias were previously cytogenetically studied by Garcia and Moreira-Filho $(2005,2008)$. The 2 individuals of $P$. maculatus from Itapetininga were not included in the cytogenetic studies.

Mitotic chromosomes were obtained from kidney cells following the technique by Gold et al. (1990) adapted for fish studies. Chromosomal morphology was determined according to the arm ratio as proposed by Levan et al. (1964). The fundamental number (FN) was calculated taking into account that metacentric $(\mathrm{m})$, submetacentric $(\mathrm{sm})$, and subtelocentric (st) chromosomes are bi-armed while acrocentric (a) chromosomes are one-armed.

Active nucleolar organizer regions (NORs) were characterized according to Howell and Black (1980). The procedure for chromosomal staining with GC-specific fluorochromes (chromomycin $\mathrm{A}_{3}, \mathrm{CMA}_{3}$ ) was performed according to Schmid (1980) with slight modifications. The identification of constitutive heterochromatin blocks followed the technique by Sumner (1972). Fluorescent in situ hybridization (FISH) was carried out according to Pinkel et al. (1986) using probes of 18S rDNA (Hatanaka and Galetti, 2004) and 5S rDNA (Martins and Galetti Jr, 1999).

\section{Molecular analyses}

Total DNA was isolated from small portions of liver tissue from each specimen following the protocol of saline extraction reported by Aljanabi and Martinez (1997). The region encompassing the mitochondrial DNA (mtDNA) ATPase 6 and 8 genes was amplified by polymerase chain reaction (PCR) using the primers L8331 (5'-AAAGCRTYRGCCTTTTAAGC3') and H9236 (5'-GTTAGTGGTCAKGGGCTTGGRTC-3') (Perdices et al., 2002).

Each PCR comprised a final volume of $25 \mu \mathrm{L}[1 \mu \mathrm{L}$ template DNA $(200 \mathrm{ng} / \mu \mathrm{L}), 1 \mu \mathrm{L}$ each primer $(10 \mathrm{pM}), 1.5 \mu \mathrm{L} \mathrm{MgCl}_{2}(25 \mathrm{mM}), 2.5 \mu \mathrm{L}$ buffer (10X), $2.5 \mu \mathrm{L}$ dNTP $(10 \mathrm{mM})$, $0.25 \mu \mathrm{L}(5 \mathrm{U})$ Taq polymerase (Fermentas), and $15.25 \mu \mathrm{L}$ distilled water]. The PCR conditions were: $94^{\circ} \mathrm{C}(3 \mathrm{~min}) ; 40$ cycles at $94^{\circ} \mathrm{C}(1 \mathrm{~min}), 58^{\circ} \mathrm{C}(1 \mathrm{~min})$, and $72^{\circ} \mathrm{C}(1 \mathrm{~min})$; a final extension at $72^{\circ} \mathrm{C}(10 \mathrm{~min})$; and a cooling period at $4^{\circ} \mathrm{C}$.

To confirm the amplification and the quality of PCR products, they were run on $1 \%$ agarose gels stained with ethidium bromide and visualized under ultraviolet light. The gels were photographed and digitalized using the Kodak EDAS software (Electrophoresis Documentation and Analysis System). 


\section{PCR-RFLP}

For PCR-RFLP analyses, we selected the same genes that were used in the phylogenetic analyses to compare the efficiency of both techniques in the identification of differences among the individuals of a single population and the relationships among species, where all collected individuals were included. The reactions of enzymatic digestion comprised a final volume of $10 \mu \mathrm{L}$ ( $3 \mu \mathrm{L}$ PCR product, $1 \mu \mathrm{L}$ buffer, $0.25 \mu \mathrm{L}$ enzyme, and $5.75 \mu \mathrm{L}$ distilled water), using the following restriction enzymes: AluI, DdeI, HaeIII, HindIII, HinfI, HpaII, MboI, and $R s a \mathrm{I}$. The digested products were separated by electrophoresis on $2 \%$ agarose gels, stained with ethidium bromide, and photographed. Each digestion pattern that was obtained from each enzyme was named by a capital letter in the order of appearance, so each haplotype was named by a letter code that was based on each restriction enzyme separately.

Based on the digestion patterns that were obtained, restriction maps were built for each haplotype, and a matrix of presence/absence of restriction sites was generated. The values of nucleotide diversity and divergence were calculated using this matrix. Nucleotide diversity values among samples were also estimated according to Nei and Tajima (1981) using the REAP software (Restriction Enzyme Analysis Package) (McElroy et al., 1992).

Based on these data, an unweighted pair group method with arithmetic mean (UPGMA) dendrogram was built using the MEGA 4.0 software (Tamura et al., 2007) to determine the relationship between species and populations.

\section{Sequencing}

Between 4 and 6 individuals per collection site were used, whenever possible, for the amplification of mitochondrial genes. In order to polarize the data, 1 specimen of Phractocephalus hemioliopterus, also belonging to family Pimelodidae, and 1 individual Rhamdia quelen, from the family Heptapteridae (sister-group of Pimelodidae), were used as outgroups. After amplification of selected genes, the PCR products were purified (ChargeSwitch PCR Clean-up kit, Invitrogen, USA) and sequenced using the BigDye ${ }^{\mathrm{TM}}$ Sequence Terminator kit, v.3.1 (Applied Biosystems, USA) according to manufacturer instructions. Both light and heavy chains of mtDNA were sequenced in an ABI PRISM 3100 Genetic Analyzer sequencer (Applied Biosystems).

The sequences were then visualized and edited using the Geneious 4.0 software (Drummond et al., 2008). They were checked in the GenBank database (http://www.ncbi.nlm. nih.gov) using BlastN, to verify their similarities to mtDNA sequences from other fish species. Afterwards, the sequences were aligned using the ClustalW algorithm (Thompson et al., 1994) applying penalties for both pairwise and multiple alignments, gap opening (10), and extension (0.2), and the alignment was verified by observing the sequence reading frames; both procedures were performed using the Geneious 4.0 software (Drummond et al., 2008). The phylogenetic analyses using neighbor-joining (NJ) and Tamura-Nei (Tamura and Nei, 1993) methods, as well as the estimation of genetic divergence among samples, were performed using MEGA4.0 (Tamura et al., 2007). Maximum parsimony analysis (MP) was carried out using the PAUP 4.0 software (Swofford, 2002) using the heuristic search (stepwise addition) with 3-bisection-reconnection (TBR) branch swapping and with all characters non-ordered and of equal weight. Gaps were regarded as missing data. Bootstrap (BT) values (Felsenstein, 1985) were calculated using 1000 replicates, and only those higher than $50 \%$ were retained. 
In order to determine if the differences in the values of genetic divergence in both PCRRFLP data and sequencing are significant, we calculated the non-parametric Spearman's correlation coefficient (Myers and Well, 2003), which evaluates an arbitrary monotonic function that describes the relationship between 2 variables, where values close or equal to 1 indicate a strong correlation.

\section{RESULTS}

\section{Cytogenetic analyses}

The populations analyzed of $P$. maculatus presented $2 \mathrm{n}=56$ chromosomes. However, they could be differentiated by their chromosomal structure. Each population presented a unique karyotype formula as follows: Angatuba, $24 \mathrm{~m}+22 \mathrm{sm}+8 \mathrm{st}+2 \mathrm{a}(\mathrm{FN}=110)$; Guapiara, $28 \mathrm{~m}+18 \mathrm{sm}+4 \mathrm{st}$ + 6a $(\mathrm{FN}=106)$; Três Lagoas, $20 \mathrm{~m}+22 \mathrm{sm}+10 \mathrm{st}+4 \mathrm{a}(\mathrm{FN}=108)$; and Terra Roxa $22 \mathrm{~m}+26 \mathrm{sm}+$ $6 \mathrm{st}+2 \mathrm{a}(\mathrm{FN}=110)($ Figure 1a-d). The individuals of $P$. heraldoi collected in Pirassununga presented $2 \mathrm{n}=56$ chromosomes and a karyotype formula of $32 \mathrm{~m}+14 \mathrm{sm}+6 \mathrm{st}+4 \mathrm{a}(\mathrm{FN}=108)$ (Figure 1e).
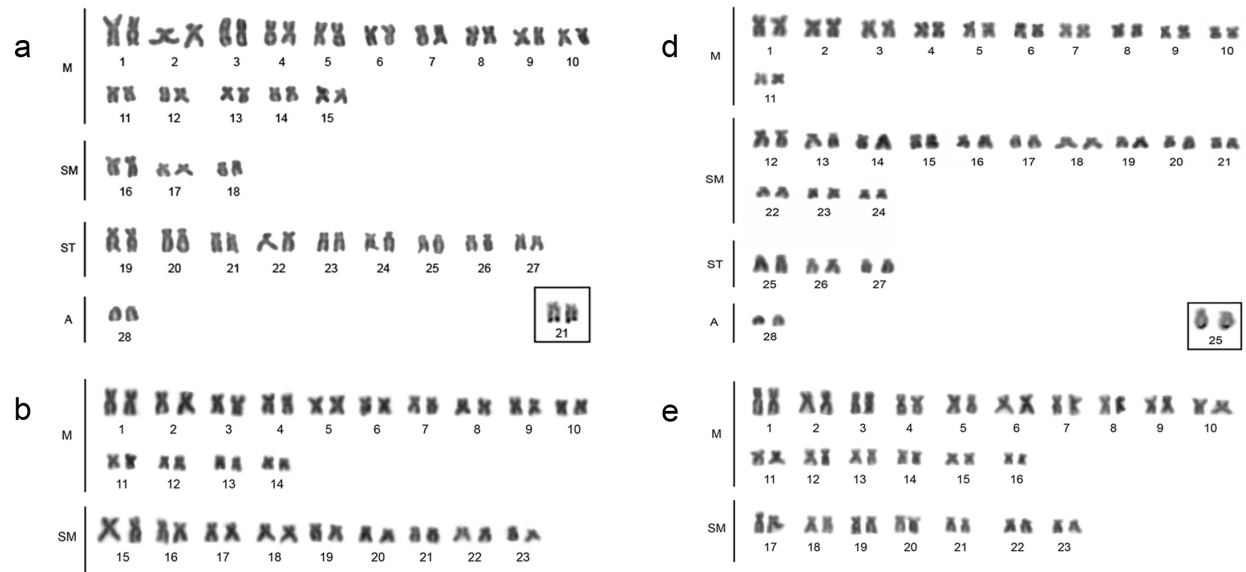

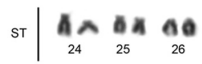

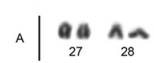

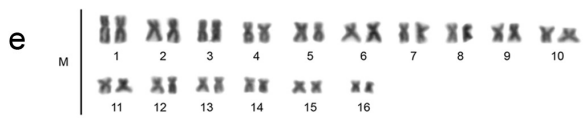

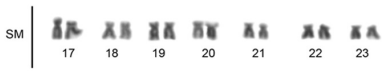

ST $\mid \begin{array}{ccc}\text { II } & \text { in } & \text { at } \\ 24 & 25 & 26\end{array}$

$A \mid \underset{27}{A D}$

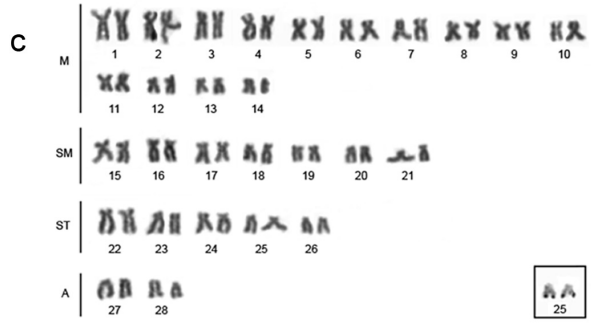

Figure 1. Karyotype submitted to Giemsa staining: Pimelodus maculatus from A. Angatuba, B. Guapiara, C. Três Lagoas, D. Terra Roxa, and E. P. heraldoi from Pirassununga. In detail the nucleolar organizing chromosomes identified through silver nitrate staining. 
The silver nitrate staining revealed a single NOR system in all populations that was located at the terminal region of long arms of a single subtelocentric chromosomal pair that was equivalent to pairs 21, 24, 25, and 26 in the populations from Angatuba, Guapiara, Três Lagoas, and Terra Roxa, respectively, and pair 25 in the population of $P$. heraldoi (Figure 1 boxes). In some specimens, differences in NOR size were observed between homologous chromosomes (data not shown), and associations between NOR-bearing pairs were frequently noticed as well. A single pair bearing fluorescent signals, equivalent to NORs, was detected in all individuals analyzed after $\mathrm{CMA}_{3}$ staining. In $P$. heraldoi, positive fluorescent signals were also observed over heterochromatic segments, showing a GC-rich composition of such heterochromatin (Figure 2a-e).

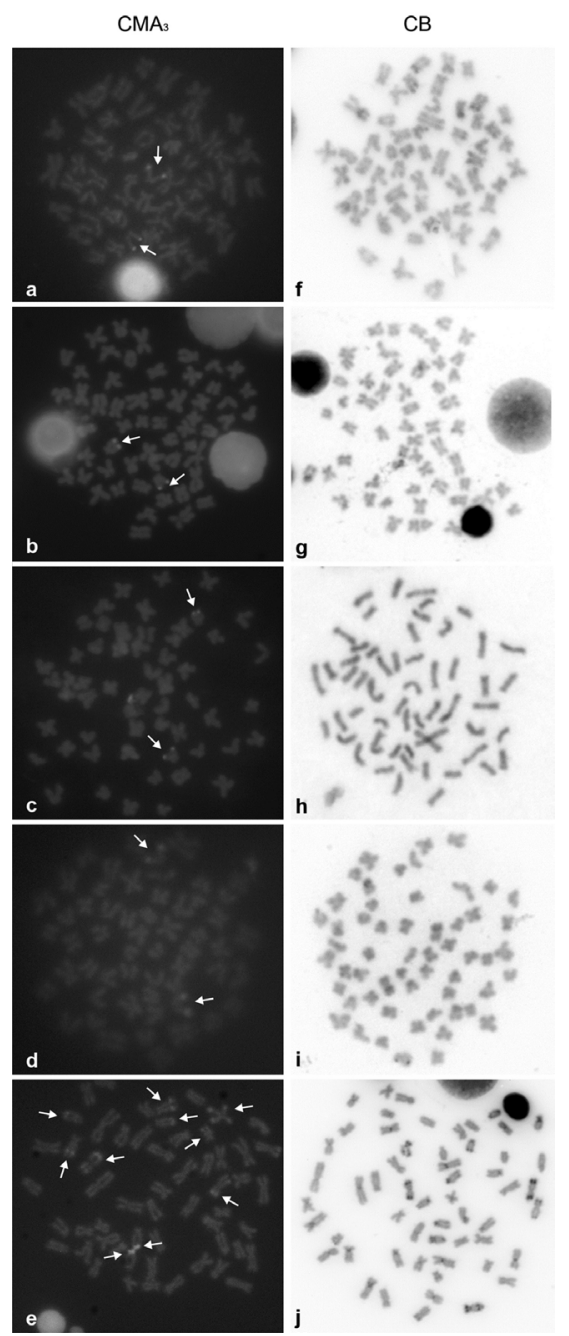

Figure 2. Metaphases of Pimelodus maculatus from: (a and f) Angatuba, (b and $\mathbf{g}$ ) Guapiara, (c and $\mathbf{h}$ ) Três Lagoas, (d and i) Terra Roxa; and (e and j) P. heraldoi from Pirassununga submitted to $\mathrm{CMA}_{3}$ staining and C-Banding. Arrows indicate the fluorescent sites obtained after $\mathrm{CMA}_{3}$ staining. 
The C-banding revealed small amounts of constitutive heterochromatin, mainly distributed over pericentromeric region. The pattern of heterochromatin location allowed us to differentiate the studied populations and demonstrated that NORs are also heterochromatic. Furthermore, a pair of submetacentric chromosomes bearing C-bands on short arms and at the terminal region of long arms was detected in P. heraldoi and was also $\mathrm{CMA}_{3}^{+}$(Figure 2f-j).

FISH using $18 \mathrm{~S}$ rDNA showed fluorescent signals coincident to NORs (Figure 3a-e). The $5 \mathrm{~S}$ rDNA sites, as revealed by FISH, were located at the terminal region of long arms of 2 subtelocentric chromosomes, similar to the NOR-bearing pair for all populations of $P$. maculatus (Figure 3f-i). Nonetheless, the synteny between both rDNA types was rejected by sequential FISH and silver nitrate staining (data not shown). Apparently, the 5S rDNA-bearing pair was the same in all of the analyzed populations. On the other hand, although characterized by a single pair bearing $5 \mathrm{~S}$ rDNA cistrons, these ribosomal sites were located at the pericentromeric region of long arms of submetacentric chromosomes in P. heraldoi (Figure 3j).
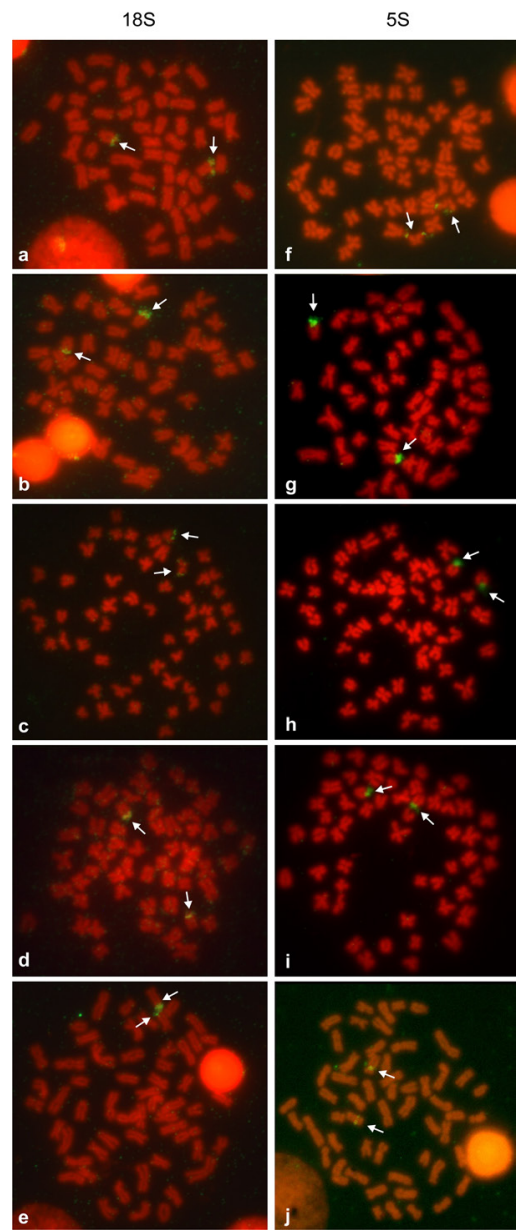

Figure 3. Metaphases of Pimelodus maculatus from: (a and f) Angatuba, (b and g) Guapiara, (c and h) Três Lagoas, (d and i) Terra Roxa; and (e and $\mathbf{j})$ P. heraldoi from Pirassununga submitted to FISH with 5S and 18S rDNA probes. Arrows indicate the fluorescent signals. 


\section{PCR-RFLP analysis of mtDNA}

The analysis of 108 specimens showed that the size of the amplified ATPase 6 and 8 gene fragments from mtDNA was about $950 \mathrm{bp}$. Two of the 8 tested restriction enzymes (DdeI and $\mathrm{MboI}$ ) did not have restriction sites within the selected mtDNA region and were excluded from the haplotype characterization.

The digestion pattern and the approximate sizes of the restriction fragments are represented in Figure 4. Based on the patterns, 5 haplotypes were identified (provided by the following enzyme sequence: AluI, HaeIII, HindIII, HinfI, HpaI, and RsaI). All populations/ species were monomorphic for their respective haplotype (the relative haplotype frequency within a sample equals $100 \%$ ). All populations of $P$. maculatus from the Upper Paraná Basin (Angatuba, Guapiara, Itapetininga, Terra Roxa, and Três Lagoas) shared a common conjugated haplotype, BABBBC, which was more related to the haplotype that was found in $P$. maculatus from the São Francisco River (AAABBC). P. fur, P. heraldoi, and Pimelodus sp presented the haplotypes CBBDBA, CBBABD, and CCBAAB, respectively.

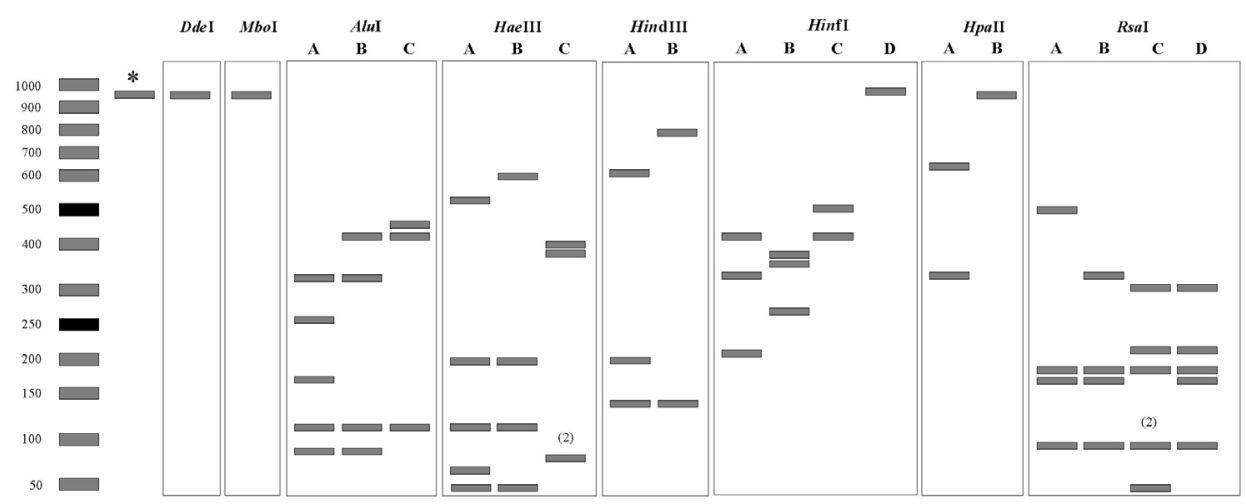

Figure 4. Illustration of the approximated size of the restriction fragments and RFLP pattern produced by digestion with endonucleases in the mtDNA ATPase 6 and 8 region of $P$. maculatus and $P$. heraldoi. The capital letters indicate the restriction patterns observed in order of appearance. *Amplified fragment, DL $=$ GeneRuler 50-bp DNA ladder (Fermentas).

The values of nucleotide divergence among the samples studied are listed in Table 1. Using on these values, we built an UPGMA dendrogram, which is shown in Figure 5. It is noticeable that all populations of $P$. maculatus are more related to each other than to the other species. Moreover, all populations from the Upper Paraná Basin might be regarded as a single evolutionary unit, inasmuch as these individuals could not be separated based on PCR-RFLP of the selected gene. P. fur and P. heraldoi presented significant divergences that were typical of distinct species, although they proved to be related to each other. On the other hand, Pimelo$d u s$ sp presented the highest divergence values and was placed at the base of the dendrogram.

\section{Sequencing analysis of mtDNA}

In spite of the amplified fragment from the ATPase 6 and 8 genes being nearly $950 \mathrm{bp}$, 
only $850 \mathrm{bp}$ of this fragment was effectively sequenced. After editing the sequences obtained, we observed a single standard haplotype per sampled species/population. Once all individuals within a population shared the same haplotype, we chose to remove the population for the final phylogenetic reconstruction; therefore, a single individual represented each population/species.

\begin{tabular}{|c|c|c|c|c|c|c|c|c|c|}
\hline Population/Species & P. fur & P. heraldoi & $\begin{array}{l}\text { P. maculatus } \\
(\mathrm{G})\end{array}$ & $\begin{array}{l}\text { P. maculatus } \\
\text { (IT) }\end{array}$ & $\begin{array}{l}\text { P. maculatus } \\
\text { (P) }\end{array}$ & $\begin{array}{l}\text { P. maculatus } \\
\text { (SF) }\end{array}$ & $\begin{array}{l}\text { P. maculatus } \\
\text { (TL) }\end{array}$ & $\begin{array}{l}\text { P. maculatus } \\
\text { (TR) }\end{array}$ & Pimelodus sp \\
\hline P. fur & & 0.0246 & 0.0664 & 0.0664 & 0.0664 & 0.0690 & 0.0664 & 0.0664 & 0.0864 \\
\hline P. heraldoi & 0.024 & & 0.0720 & 0.0720 & 0.0720 & 0.0735 & 0.0720 & 0.0720 & 0.0555 \\
\hline P. maculatus $(\mathrm{G})$ & 0.054 & 0.045 & & 0.0000 & 0.0000 & 0.0058 & 0.0000 & 0.0000 & 0.1076 \\
\hline P. maculatus (IT) & 0.054 & 0.045 & 0.000 & & 0.0000 & 0.0058 & 0.0000 & 0.0000 & 0.1076 \\
\hline P. maculatus $(\mathrm{P})$ & 0.058 & 0.049 & 0.004 & 0.004 & & 0.0058 & 0.0000 & 0.0000 & 0.1076 \\
\hline P. maculatus (SF) & 0.055 & 0.049 & 0.006 & 0.006 & 0.010 & & 0.0058 & 0.0058 & 0.1076 \\
\hline P. maculatus (TL) & 0.056 & 0.048 & 0.002 & 0.002 & 0.006 & 0.009 & & 0.0000 & 0.1076 \\
\hline P. maculatus (TR) & 0.054 & 0.045 & 0.000 & 0.000 & 0.004 & 0.006 & 0.002 & & 0.1076 \\
\hline Pimelodus sp & 0.089 & 0.074 & 0.073 & 0.073 & 0.077 & 0.077 & 0.076 & 0.073 & \\
\hline
\end{tabular}

$\mathrm{G}=$ Guapiara; IT = Itapetininga; P = Paranapanema; SF = São Francisco; TR = Terra Roxa; TL = Três Lagoas.

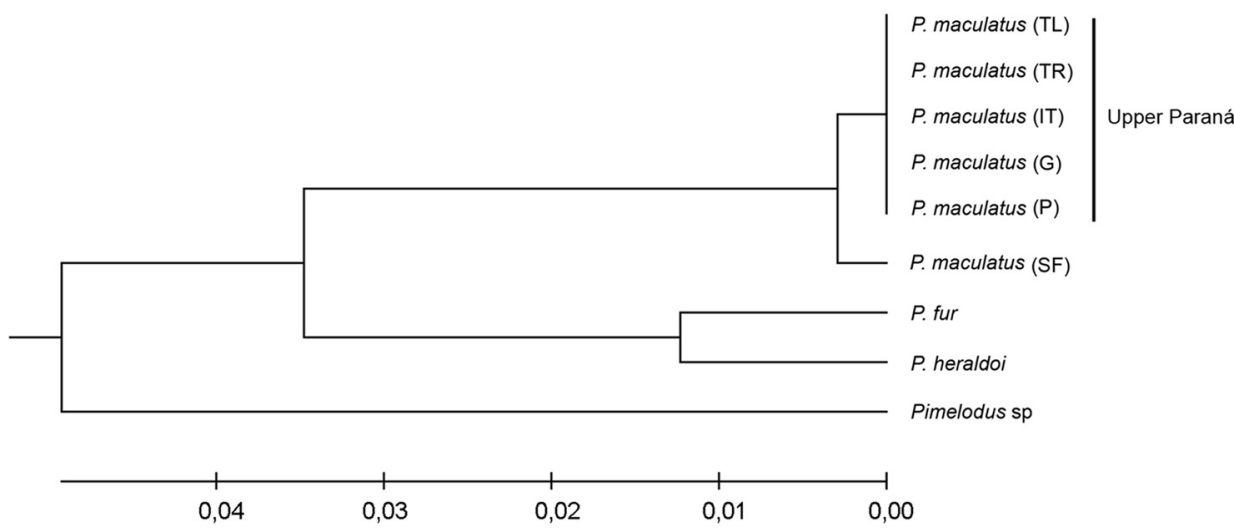

Figure 5. UPGMA dendrogram based on the nucleotide divergence estimated by PCR-RFLP analysis, presenting the evolutionary relationship of the Pimelodus species/populations analyzed. G = Guapiara; $\mathrm{IT}=$ Itapetininga; $\mathrm{P}=$ Paranapanema; $\mathrm{SF}=$ São Francisco; TR = Terra Roxa; TL = Três Lagoas.

We observed that the estimated size of restriction fragments via PCR-RFLP was very similar or identical to the actual restriction fragment sizes within the sequences analyzed. However, some restriction sites were not detected in some sequences because of the smaller size of the sequences relative to the total amplified fragment length. The differences in the position of recognizable sites by the tested enzymes were related to events of base substitution that resulted in synonymous mutations in the amino acid sequence. Differences throughout the remaining nucleotides in the gene are caused by nucleotide substitutions and allowed a more refined estimation of the evolutionary relationships in the groups studied (data not shown).

The same interrelationships that were observed in the dendrogram that was based on PCR-RFLP were recovered by the NJ and MP analysis with branches that were supported by 
high BT values and significant genetic divergences (Table 1). Based on this data, the NJ tree was chosen to be presented. It is noteworthy that the populations of $P$. maculatus were grouped in the same clade. No clear distinction among individuals from the Upper Paraná Basin was detected. The BT value of 55\% that supports the clade that grouped most of the P. maculatus populations is considered weak; based on this, these individuals can be regarded as part of the same evolutionary unit. It is also noticeable that the samples of $P$. maculatus from the Upper Paraná Basin were related to $P$. maculatus from the São Francisco River, and $P$. fur appeared to be related to $P$. heraldoi. Once more, Pimelodus sp was placed as a basal group amongst Pimelodus species (Figure 6).

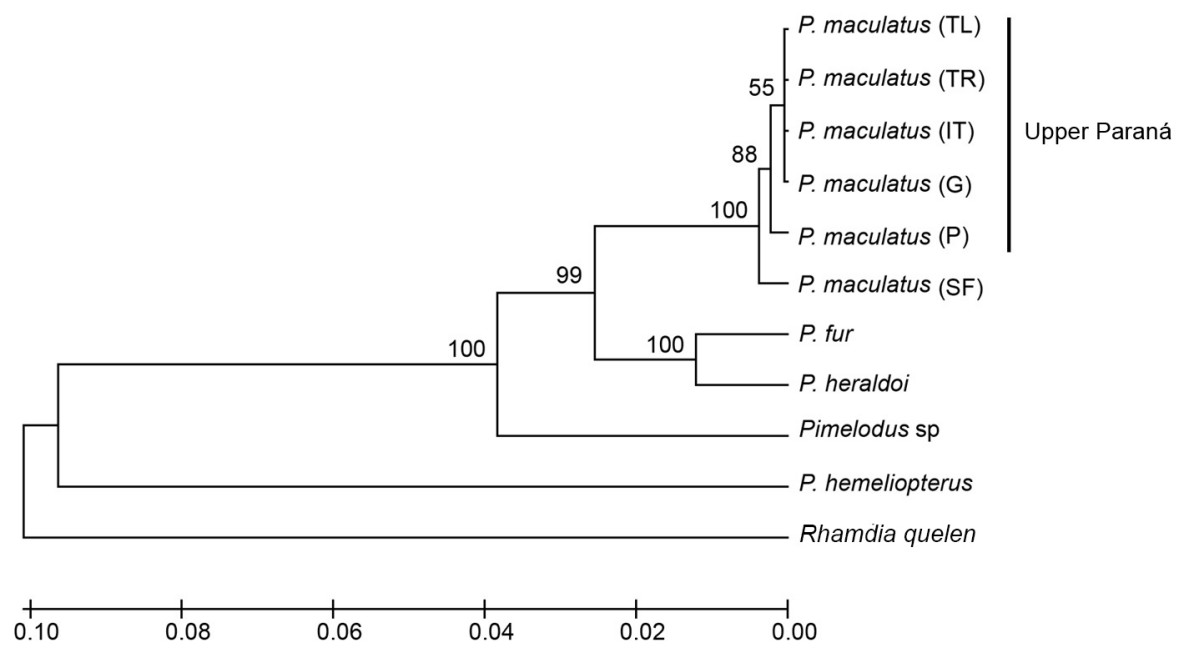

Figure 6. Neighbor-joining tree of Tamura-Nei distance of ATPase 6 and 8 from Pimelodus populations/species sampled. Bootstrap values $\geq 50$ are shown. $\mathrm{G}=$ Guapiara; $\mathrm{IT}=$ Itapetininga; $\mathrm{P}=$ Paranapanema; $\mathrm{SF}=\mathrm{São}$ Francisco; $\mathrm{TR}=$ Terra Roxa; $\mathrm{TL}=$ Três Lagoas.

The Spearman's correlation coefficient that was estimated for the nucleotide divergence values is 0.9989 (Table 1), indicating a high positive correlation between both variables. This result demonstrates that the divergence values that were obtained in both methods and used in the evolutionary reconstructions are significantly similar, revealing that both methods can be used for species identification.

\section{DISCUSSION}

\section{Cytogenetic data}

The available cytogenetic data so far show that the diploid number within the genus Pimelodus ranges from $2 \mathrm{n}=54$ chromosomes (Garcia and Moreira-Filho, 2005) to $2 \mathrm{n}=58$ (DellaRosa et al., 1980), and most populations present $2 n=56$ chromosomes. There is great karyotypic variability in this group (Swarça et al., 2000), including cases of supernumerary chromosomes (Borin and Martins-Santos, 2004) and structural polymorphisms (Mazzuchelli et al., 2007). 
From a cytogenetic viewpoint, $P$. maculatus is the most widely studied species within the family Pimelodidae. Research that was carried out in several hydrographic basins indicated that the populations of $P$. maculatus might differ in relation to their karyotype structure in spite of presenting some similarities, such as the maintenance of the diploid number, the prevalence of $\mathrm{m} / \mathrm{sm}$ chromosomes, the number and location of GC-rich NORs, and reduced heterochromatin content (Swarça et al., 2000).

Treco et al. (2008) proposed the occurrence of 3 karyotypic classes (clustering metaand submetacentric chromosomes and subtelocentric and acrocentric ones), which would comprise the whole chromosomal variation observed in P. maculatus. Under this criterion, the 3 classes would be represented by the following karyotype formulae: 1) $40 \mathrm{~m} / \mathrm{sm}+16 \mathrm{st} / \mathrm{a}$, 2) $44 \mathrm{~m} / \mathrm{sm}+12 \mathrm{st} / \mathrm{a}$, and 3) $38 \mathrm{~m} / \mathrm{sm}+18 \mathrm{st} / \mathrm{a}$. These authors also suggested that the class with $40 \mathrm{~m} / \mathrm{sm}+16 \mathrm{st} / \mathrm{a}$ would be predominant in the Upper Paraná Basin, indicating a higher karyotype conservativeness within populations from this hydrographic system and the role of inversions and/or translocations.

Although belonging to the Upper Paraná Basin, the populations that were analyzed in this study fit or resemble the second karyotypic class that was proposed by Treco et al. (2008). These chromosomal differences are thought to be subtle, and they might be a consequence of differential condensation patterns in the chromosomal preparations as well. Therefore, despite the karyotypic differences in the studied populations of $P$. maculatus, they are not quite divergent and can be related to the fixation of distinct chromosomal rearrangements though the evolutionary pathways of each population.

Such small differences in the chromosomal constitution of $P$. maculatus might neither alter gene groups nor present position effects, inasmuch as the external morphology would remain unchanged. Based on this feature and on chromosomal differences, several authors have speculated that distinct fish species would compose species complexes. This accounts for the fact that some widely distributed species lacking any phenotypic divergence might be under a remarkably stable selection or undergoing some kind of developmental canalization over the expression of morphological traits (Martin and Bermingham, 2000).

The representatives of the 4 populations of $P$. maculatus and $P$. heraldoi that were cytogenetically analyzed in this study presented $2 n=56$ chromosomes, characterizing a recurrent result for samples of this species. This chromosomal number is called the ancestor diploid value for Siluriformes by some authors (Oliveira and Gosztonyi, 2000), and it is often reported in the family Pimelodidae (Swarça et al., 2000). The differences in the chromosomal structure that are reported in the populations analyzed are likely a result of non-Robertsonian rearrangements, which have been considered to be the main mechanism of variation within this family (Garcia and Moreira-Filho, 2005).

In general, Siluriformes species have small amounts of heterochromatin that are mainly located at pericentromeric or terminal positions. In this study, a few differences in the heterochromatin location were observed in the populations analyzed, which showed heterochromatic blocks preferentially at pericentromeric region and on NORs. This pattern is similar to that observed for the genus Pimelodus (Souza et al., 2004).

The occurrence of a single NOR-bearing pair and location of NORs at the terminal position on long arms of st chromosomes match the pattern that was already reported for P. maculatus (Swarça et al., 2000). Based on the available cytogenetic reports, terminal NORs on long arms of $\mathrm{sm} / \mathrm{st}$ chromosomes can be considered a plesiomorphic feature for Pimelodus, whereas the NORs 
located on the short arms in P. argenteus and P. mysteriosus (Souza et al., 2004) represent apomorphies. In this study, FISH analysis with an 18S rDNA probe confirmed the occurrence of a single NOR system and its location; a similar situation was observed by Souza et al. (2004).

The association between NORs and GC-specific fluorochromes has been widely reported in many fish groups (Garcia et al., 2003). Most reports show that $\mathrm{CMA}_{3}$ or mitramycin staining yields fluorescent signals that are equivalent to NORs. However, heterochromatic regions can be occasionally marked by these fluorochromes (Garcia and Moreira-Filho, 2005). The populations analyzed in this study presented GC-rich NORs, following a pattern that was previously reported in other Pimelodus species (Swarça et al., 2000; Souza et al., 2004). Differences related to the composition of heterochromatin blocks, which were already observed in other species of this genus (Garcia and Moreira-Filho, 2005), could be observed by $\mathrm{CMA}_{3}$ staining, demonstrating that the heterochromatin nature is variable within this group.

As for the 5S ribosomal genes, little is known about their chromosomal location in Neotropical fishes. Nonetheless, the localization of 5S rDNA sites has been proven to represent an important marker in fish studies (Martins and Galetti Jr, 1999).

Amongst Siluriformes, there are few reports addressing the location of 5S rRNA genes (Hypostomus and Upsilodus, Kavalco et al., 2004) inasmuch as the discussion about the location and number of such genes in this fish group remains incipient.

The number and the localization of minor ribosomal genes were conserved in the 4 populations that were analyzed, and a putative synteny with $18 \mathrm{~S}$ rRNA genes was rejected. In $P$. heraldoi, the position of 5S RNA genes was differentiated, albeit the number of sites remained the same. A nonsyntenic localization of these genes in relation to $45 \mathrm{~S}$ rDNA is the most reported condition, and it has been regarded as an ancestor trait of gene organization in fish (Martínez et al., 1996).

Most Neotropical species in which the 5S rDNA location was analyzed have 2 chromosomal pairs bearing 5S rRNA genes (Almeida-Toledo et al., 2002). On the other hand, the data available for the genus Pimelodus indicate that the number of chromosomes bearing such genes is variable, ranging from 4 (P. fur) to 6 (P. maculatus and Pimelodus sp) (Garcia and Moreira-Filho, 2008). It should be pointed out that the populations/species from the Upper Paraná Basin differ from Pimelodus collected in the São Francisco River, mainly because of their lower number of $5 \mathrm{~S}$ rDNA sites.

The location of $5 \mathrm{~S}$ ribosomal genes in the population of P. maculatus from the São Francisco River (MG-Brazil) reported by Garcia and Moreira-Filho (2008) differed from the pattern in the population of Pimelodus sp. from the same locality where they were located at the terminal position on long arms of an sm chromosomal pair in the latter, which was attributed to a putative paracentric inversion by the authors. Although the 4 populations of $P$. maculatus that were analyzed in this study had a single 5S rDNA-bearing pair, they share a common terminal location with a chromosomal pair in the population from the São Francisco River. This fact suggests that this chromosomal pair might be a species-specific marker; hence, the interpretation that the terminal location could be derived from a paracentric inversion in the São Francisco population is refuted. On the other hand, P. fur, P. heraldoi, and Pimelodus sp seem to share a common distribution pattern of ribosomal sites in chromosomes with very similar size and structure.

In relation to the terminal location of $5 \mathrm{~S}$ rRNA genes detected in this study, Martins and Galetti Jr. (1999) suggested that a preferable interstitial location would act as a protec- 
tive strategy, avoiding transposition and exchanges within these sequences, which would be related to the high degree of conservativeness of this ribosomal gene. Instead, the Siluriformes species that were analyzed so far show the trend of a terminal 5S rDNA location, particularly in those species with high chromosomal numbers (Garcia and Moreira-Filho, 2008). However, this tendency will eventually be confirmed or refuted as the number of studies using such markers in this fish group increases.

\section{Molecular data}

There are few genetic-molecular studies in Siluriformes. This is particularly true for species from Neotropical regions. The majority of molecular studies available for the genus Pimelodus use isozymes (Renesto et al., 2000) and random amplification of polymorphic DNA (RAPD) markers (Almeida et al., 2003) to differentiate distinct species within this genus. Only recently, P. albicans was the focus of studies involving the sequencing of mitochondrial genes, which revealed a remarkable haplotype diversity among the samples analyzed and confirmed the occurrence of a species complex (Vergara et al., 2008).

Despite the evident cytogenetic differentiation among the populations that were studied, molecular studies have shown a low divergence between $P$. maculatus populations, as reported by Almeida et al. (2003) who used RAPD markers. In that study, a single and large homogeneous population of this species was detected throughout the Tietê River, while some structuring was observed along the Paranapanema River, probably because of the presence of waterfalls throughout this river.

Restriction profiles of mtDNA have been widely used in studies of population structure, biogeography, and species characterization. Among Siluriformes, the application of such methodology has proven to be useful to distinguish species and their hybrid forms and to identify potential markers for conservation and management programs. These studies involved species of the genus Clarias (Mohindra et al., 2007), whose distinct species were easily discriminated, and each population presented some specific haplotypes that were helpful in their identification.

In this study, PCR-RFLP markers provided a clear separation between the studied species, and the digestion patterns yielded species-specific mtDNA profiles. All specimens of P. maculatus from Upper Paraná, even those belonging to distinct populations, had the same restriction pattern, demonstrating that they share a remarkable degree of genetic similarity that is undifferentiated at this marker.

Although the PCR-RFLP technique has some limitations for identifying species because it can detect only mutations that affect the enzyme restriction sites both the PCR-RFLP and sequencing methodologies indicated the same interrelationship pattern, and they were equally effective in differentiating the groups studied. Based on the sequencing of mitochondrial genes, our observation was that both nucleotide mutations in the restriction sites and those throughout the sequences are mostly related to synonymous substitutions in the coded proteins, which do not affect the protein and its function directly.

Although the populations of P. maculatus from the Upper Paraná and São Francisco River could not be separated by morphological data in our study, the PCR-RFLP and sequencing data demonstrated that they compose genetically distinct but related groups, which was supported by high BT values. The P. maculatus population from the Paranapanema River was differentiated from the other populations from the Upper Parana Basin in the NJ and MP 
analysis, but it had weak BT support (55\%). This fact can be explained by the location of this individual because other molecular studies indicated that the presence of waterfalls in the Paranapanema River may lead to genetic differentiation among fish species (Almeida et al., 2003). P. fur and $P$. heraldo $i$ were also related to each other. This relationship is also observed in their morphology because of the similar pattern of irregular spots on the body of both species. These data show that in spite of the karyotypic similarities that were reported by Garcia and Moreira-Filho (2005), the species of Pimelodus from the São Francisco River are more related to other representatives within the genus than each other, which disagrees with their previous assumptions. Possibly, the chromosomal resemblance among these species could be related to environmental pressures in the São Francisco River, resulting in similar evolutionary forces during the karyoevolutionary pathway of these fish in the region.

\section{Application of sequencing, chromosomal, and PCR-RFLP markers in fish conservation}

RFLP markers are widely used in Brazilian fish culture, including programs of genetic conservation for repopulation and the formation of genetic banks. This technique is preferred to sequencing because it allows the analysis of a large number of individuals simultaneously at significantly lower costs. In contrast, cytogenetic techniques have been neglected for a long time in such analyses, mainly because of limitations of population studies related to the time spent on preparations and banding procedures (Toledo-Filho et al., 1999).

The correlation coefficient between the obtained PCR-RFLP divergence values and sequence direct analysis were very similar, and the slight differences were not significant: the three topologies based on both values were identical. In spite of the PCR-RFLP limitations in detecting all variation within an amplified gene fragment, this method can be comparable to sequencing mtDNA data and equally effective in identifying Pimelodus species, thus confirming its potential as a useful marker in management programs. Furthermore, because it is cost-saving in relation to gene sequencing, this technique serves a practical application for this purpose.

Although it allowed us to differentiate species, both PCR-RFLP and gene sequencing were unable to discriminate populations of P. maculatus from the Upper Paraná Basin. Based on these methodologies, these samples should be regarded as a single evolutionary unit; therefore, individuals from these populations could be used to form genetic pools. Nonetheless, each population presents distinctive chromosomal features that were mainly related to karyotype macrostructure. These differences could act as reproductive barriers because hybrids from the different cytotypes were not found. The probable gene and meiotic unbalance in these crosses could lead to total failure in breeding projects aiming to form genetic banks.

The presence of distinct chromosomal formulae among populations does not imply the existence of a species complex in P. maculatus (as indicated by their high genetic similarity); rather, it suggests the occurrence of different cytotypes in the group because other cytogenetic features, such as NORs and the location and number of 5S rDNA sites were conserved. It should be pointed out that the sample size in one of the populations studied (Itapetininga) was small (different haplotypes might not have been sampled) and neither cytogenetic study was performed. However, the deconstruction of a species complex in P. maculatus should not be extended to other hydrographic basins because their populations have not been genetically analyzed.

The data from this study confirm the potential of PCR-RFLP markers in the identifica- 
tion of fish species, and they point out the relevance of a multi-approach analysis including cytogenetic techniques in groups that are characterized by great chromosomal variability to determine the genetic stocks for both management and fish culture programs.

\section{ACKNOWLEDGMENTS}

The authors would like to thank Carlos Eduardo Lopes and Yoshimi Sato from the Companhia de Desenvolvimento dos Vales do São Francisco e do Parnaíba for their assistance in collecting the specimens that were analyzed in this study. Research supported by Coordenação de Aperfeiçoamento de Pessoal de Nível Superior, Fundação de Amparo à Pesquisa do Estado de São Paulo, Fundação de Amparo à Pesquisa do Estado da Bahia (\#PPP039/2011) and Conselho Nacional de Desenvolvimento Científico e Tecnológico.

\section{REFERENCES}

Aljanabi SM and Martinez I (1997). Universal and rapid salt-extraction of high quality genomic DNA for PCR-based techniques. Nucleic Acids Res. 25: 4692-4693.

Almeida-Toledo LF, Ozouf-Costaz C, Foresti F, Bonillo C, et al. (2002). Conservation of the 5S-bearing chromosome pair and co-localization with major rDNA clusters in five species of Astyanax (Pisces, Characidae). Cytogenet. Genome Res. 97: 229-233.

Almeida FS, Sodré LMK and Contel EPB (2003). Population structure analysis of Pimelodus maculatus (Pisces, Siluriformes) from the Tietê e Paranapanema Rivers (Brazil). Genet. Mol. Biol. 26: 301-305.

Borin LA and Martins-Santos IC (2004). Study on karyotype and occurrence of B chromosomes in two endemic species of the genus Pimelodus (Siluriformes, Pimelodidae) from the river Iguaçu. Hereditas 140: 201-209.

Della-Rosa VA, Bertollo LAC, Ferrari I and Moreira-Filho O (1980). Estudos citogenéticos de peixes da Amazônia. II Ordem Siluriformes. Ciênc. Cult. 32-735.

Drummond AJ, Ashton B, Cheung M and Heled J (2008). Geneious v4.0. Available at [http://www.geneious.com] Accessed February 17, 2009.

Felsenstein J (1985). Confidence limits on phylogenies: An approach using the bootstrap. Evolution 39: 783-791.

Garcia C, Moreira-Filho O, Bertollo LAC and Centofante L (2003). B chromosomes and natural triploidy in Rhamdia sp. (Pisces, Siluriformes, Heptapteridae). Cytologia 64: 403-411.

Garcia C and Moreira-Filho O (2005). Cytogenetical analyses in three fish species of the genus Pimelodus (Siluriformes, Pimelodidae) from rio São Francisco: considerations about the karyotypical evolution in the genus. Neotrop. Ichthyol. 3: $285-290$.

Garcia C and Moreira-Filho O (2008). Localization of ribosomal genes in three Pimelodus species (Siluriformes, Pimelodidae) of the São Francisco River: 5S genes as species markers and conservation of the 18S rDNA sites. Genet. Mol. Biol. 31: 261-264.

Gold JR, Li YC, Shipley NS and Powers PK (1990). Improved methods for working with fish chromosomes with a review of metaphase chromosome banding. J. Fish Biol. 37: 563-575.

Hatanaka T and Galetti PM (2004). Mapping of the 18S and 5S ribosomal RNA genes in the fish Prochilodus argenteus Agassiz, 1829 (Characiformes, Prochilodontidae). Genetica 122: 239-244.

Howell WM and Black DA (1980). Controlled silver-staining of nucleolus organizer regions with a protective colloidal developer: a 1-step method. Experientia 36: 1014-1015.

Kavalco KF, Pazza R, Bertollo LA and Moreira-Filho O (2004). Gene mapping of 5S rDNA sites in eight fish species from the Paraiba do Sul river basin, Brazil. Cytogenet. Genome Res. 106: 107-110.

Levan A, Fredga K and Sandberg HA (1964). Nomenclature for centromeric position on chromosomes. Hereditas 52: 201-220.

Lundberg JG and Littmann MW (2003). Family Pimelodidae (Long-whiskered catfishes). In: Check List of the Freshwater Fishes of South and Central America (Reis RE, Kullander SO and Ferraris CJ Jr, eds.). Edipucrs, Porto Alegre, 432446.

Martin AP and Bermingham E (2000). Regional endemism and cryptic species revealed by molecular and morphological analysis of a widespread species of Neotropical catfish. Proc. Biol. Sci. 267: 1135-1141. 
Martins C and Galetti PM, Jr. (1999). Chromosomal localization of 5S rDNA genes in Leporinus fish (Anostomidae, Characiformes). Chromosome Res. 7: 363-367.

Martínez JL, Moran P, García-Vásquez E and Pendás AM (1996). Chromosomal localization of the major and 5S rRNA genes in the European eel (Anguilla anguilla). Cytogenet. Cell Genet. 73: 149-152.

Mazzuchelli J, Swarca AC and Dias AL (2007). Structural chromosome polymorphism in a Pimelodus maculatus La Cepede, 1803 population (Siluriformes, Pimelodidae) from the Paranapanema River basin, PR, Brazil. Braz. J. Biol. 67: 935-937.

McElroy D, Moran P, Bermingham E and Kornfield I (1992). REAP: an integrated environment for the manipulation and phylogenetic analysis of restriction data. J. Hered. 83: 157-158.

Mohindra V, Singh RK, Palanichamy M and Ponniah AG (2007). Genetic Identification of three species of the genus Clarias using allozyme and mitochondrial DNA markers. J. Appl. Ichthyol. 23: 104-109.

Myers JL and Well AD (2003). Research Design and Statistical Analysis. 2nd edn. Mahwah: Lawrence Erlbaum Associates, New Jersey.

Nei M and Tajima F (1981). DNA polymorphism detectable by restriction endonucleases. Genetics 97: 145-163.

Oliveira C and Gosztonyi AE (2000). A cytogenetic study of Diplomystes mesembrinus (Teleostei, Siluriformes, Diplomystidae) with a discussion of chromosome evolution in Siluriforms. Caryologia 53: 31-37.

Perdices A, Bermingham E, Montilla A and Doadrio I (2002). Evolutionary history of the genus Rhamdia (Teleostei: Pimelodidae) in Central America. Mol. Phylogenet. Evol. 25: 172-189.

Pinkel D, Straume T and Gray JW (1986). Cytogenetic analysis using quantitative, high-sensitivity, fluorescence hybridization. Proc. Natl. Acad. Sci. U. S. A. 83: 2934-2938.

Renesto E, Zawadzki CH and Revaldaves E (2000). Genetic evidence for two species of the genus Pimelodus Lacépède, 1803 (Siluriformes, Pimelodidae) in the Iguaçu River (Brazil). Genet. Mol. Biol. 23: 809-813.

Schmid M (1980). Chromosome banding in amphibia. IV. Differentiation of GC- and AT-rich chromosome regions in Anura. Chromosoma 77: 83-103.

Souza L, Swarça AC and Dias AL (2004). Analyses of the nucleolus organizer region in 5 species of the genus Pimelodus (Siluriformes, Pimelodidae) using AgNO3, CMA3 and FISH with the 18S rDNA probe. Caryologia 57: 145-151.

Sumner AT (1972). A simple technique for demonstrating centromeric heterochromatin. Exp. Cell Res. 75: 304-306.

Swarça AC, Giuliano-Caetano L and Dias AL (2000). Analyses of nucleolus organizer regions and heterochromatin of Pimelodus maculatus (Pisces, Pimelodidae). Genetica 110: 97-100.

Swarça AC, Giuliano-Caetano L and Dias AL (2000). Cytogenetics of species of the families Pimelodidae and Rhamdiidae (Siluriformes). Genet. Mol. Biol. 23: 589-593.

Swofford DL (2002). PAUP*. Phylogenetic Analysis Using Parsimony (*and other methods). Version 4. Sinauer Associates, Sunderland.

Tamura K and Nei M (1993). Estimation of the number of nucleotide substitutions in the control region of mitochondrial DNA in humans and chimpanzees. Mol. Biol. Evol. 10: 512-526.

Tamura K, Dudley J, Nei M and Kumar S (2007). MEGA4: Molecular Evolutionary Genetics Analysis (MEGA) software version 4.0. Mol. Biol. Evol. 24: 1596-1599.

Thompson JD, Higgins DG and Gibson TJ (1994). CLUSTAL W: improving the sensitivity of progressive multiple sequence alignment through sequence weighting, position-specific gap penalties and weight matrix choice. Nucleic Acids Res. 22: 4673-4680.

Toledo-Filho AS, Calcagnotto D, Bernardino G and Fernandes-matioli FMC (1999). Projetos de Bancos Genéticos na Piscicultura Brasileira. Cadernos de Ictiogenética 5, 1st edn., CCS/USP, São Paulo.

Treco FR, Malabarba LR, Giuliano-Caetano L and Dias AL (2008). Cytogenetic study of two species of the family Pimelodidae (Siluriformes) collected in lago Guaíba, Rio Grande do Sul, Brazil. Neotrop. Ichthyol. 6: 87-92.

Vergara J, Azpelicueta MM and Garcia C (2008). Phylogeography of the Neotropical catfish Pimelodus albicans (Siluriformes: Pimelodidae) from río de la Plata basin, South America, and conservation remarks. Neotrop. Ichthyol. 6: $75-85$. 